\title{
Petrology, Geochemistry and Economic Aspects of the Alkaline Dyke in Anta Gorda Region, Doutor Ulysses, Paraná, Brazil
}

\author{
José Augusto Simões Neto', Leonardo Fadel Cury'1, Marcell Leonard Besser², \\ Ariadne Borgo', SallaTalvikki Eeva1 \\ ${ }^{1}$ Departamento de Geologia, Federal University of Paraná, Curitiba, Brazil \\ ${ }^{2}$ Geologic Survey of Brazil (CPRM), Curitiba, Brazil \\ Email: gu_to_ja@hotmail.com
}

How to cite this paper: Neto, J.A.S., Cury, L.F., Besser, M.L., Borgo, A. and Eeva, S.T. (2019) Petrology, Geochemistry and Economic Aspects of the Alkaline Dyke in Anta Gorda Region, Doutor Ulysses, Paraná, Brazil. Open Journal of Geology, 9, 378-394.

https://doi.org/10.4236/ojg.2019.97025

Received: June 10, 2019

Accepted: July 28, 2019

Published: July 31, 2019

Copyright $\odot 2019$ by author(s) and Scientific Research Publishing Inc. This work is licensed under the Creative Commons Attribution International License (CC BY 4.0).

http://creativecommons.org/licenses/by/4.0/

(c) (i) Open Access

\begin{abstract}
The rock types of the alkaline dyke from Anta Gorda region, in the township of Doutor Ulysses (State of Paraná), encompass three lithological groups that have been individualized for their distinct textural, structural, mineralogical and/or geochemical characteristics: phonolites s.s., amygdaloidal phonolites and trachyphonolites. These are rocks with magmatic derivation, in which the most important differentiation processes interpreted were immiscibility and fractional crystallization from the ultrabasic mantellic source with primary magma. Fenite epidotes were also classified in the study area, probably product of fenitization of the granitic wall rock. Due to the geographical proximity, some similarities between the phonolites and the rocks from the Barra do Teixeira alkaline plug or the Banhadão Alkaline Complex were expected. However, the results of the petrographic and geochemical analysis point to major resemblance between the phonolites and the lithotypes of the Mato Preto Alkaline Complex. The studied rocks contain concentrations of economic interest of important chemicals elements, mainly Rare Earth Elements-REE, trace elements and mineral substances, such as zeolites and fluorites.
\end{abstract}

\section{Keywords}

Phonolites, Rare Earth Elements, Epidote, Mineralization

\section{Introduction}

Anta Gorda is situated in the municipality of Doutor Ulysses, approximately 12 $\mathrm{km}$ southwest of the homonymous city. Two references can be given for the lo- 
cation of the outcrops of the studied area:

1) The headquarters of the Anta Gorda Farm;

2) A secondary road (access road) to the Boca Rica Farm.

Currently, the roads with best access conditions are:

1) PR-092, leaving from the capital of Paraná, Curitiba. This highway is paved until the city of Cerro Azul, and leads to Doutor Ulysses;

2) Continuing towards the town of CerradoVarzeão, there is an exit at Fazenda Olho D’Água, where another road leads to Anta Gorda (Figure 1).

The petrographic characterization of the intrusive alkaline rocks of Anta Gorda, combined with the geochemical techniques applied, resulted in the interpretation and petrogenetic correlation of these rocks. The present study also focused on the search for evidence of metasomatism involving the aforementioned intrusions and their contacts. Thus, products of alterations were analyzed as well. Besides contributing to the interpretation of the genesis of these rocks, the identification of the fluid phase of alkaline magma has allowed for a better understanding of incompatible elements, which are common during mineralization.

Since Alkaline Complexes and the associated rocks might host mineralizations of niobium, titanium, phosphates and fluorides, as well as Rare Earth Elements-REE, generally associated with carbonate rocks, they are frequently targets for mineral exploration. The genesis of these rocks can still be associated with kimberlite parental magmas. Therefore, in addition to the petrographic and geochemical characterization of the phonolitic rocks, this work has aimed to study possibilities of mineralization of the elements mentioned, and elaborate prospective guides, which would be applicable mainly for this type of rocks in the Southern Ribeira Belt (Figure 1).

\section{Materials and Methods}

The samples were collected during two fieldworks in the Ribeira Valley. These samples were submitted to a selection processes for the preparation of thin sections.

For the petrographic analysis, eight thin section samples of the study area were prepared and described, and one thin section belonging to the Mato Preto Complex was also described. The equipment used in these analyzes were mainly Olympos Petrographic Microscopes, besides equipment for capturing micrographs.

Three samples were selected for chemical analyses. The material used in the tests derived from areas adjacent to the cut of the petrographic sections to allow comparison between the results of these techniques. For the three samples, analyzes of diffractometry were conducted with Philips Analytical X-Ray B.V equipment, with $\mathrm{Cu}$ Anode material and angle of reading $2 \mathrm{Th}$ of beginning $3^{\circ}$ and term $70^{\circ}$. The samples were also analyzed with X-ray Fluorescence using Philips equipment and two methodological lines. In the first, the unaltered rock was initially milled and then mounted on molten beads (quantitative methodology). In the second line, samples were milled and then assembled into pellets 


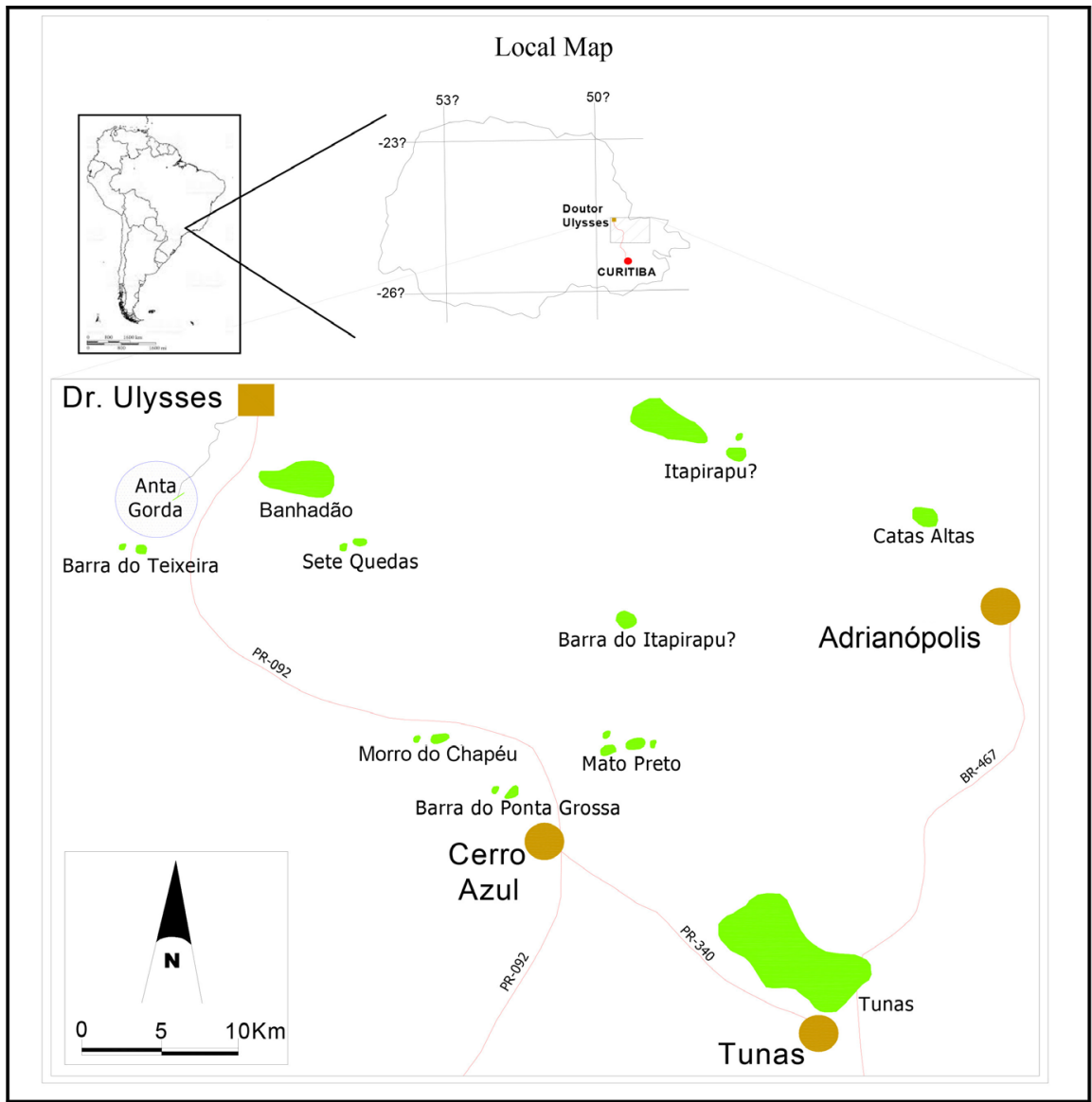

Figure 1. Localization and access to Anta Gorda region (in blue); main Alkaline Complexes of Ribeira River Valley (in green).

with boric acid and wax (semi-quantitative methodology). All samples for which fluorescence analysis was performed were also submitted to fire loss tests (L.O.I.).

Finally, several softwares were applied in the treatment of these materials. For the interpretation of the diffractograms, PC-APD, Diffraction software was used for the treatment of fluorescence data, IGpet and CIPW. Image and text editing was done with AutoCAD 2004 and Microsoft Word, respectively.

\section{Geology of Alkaline Complexes}

Studies of alkaline rocks are numerous, driven primarily by vast economic possibilities, but also by the scientific interest in the investigation of complex and rare processes of magmatic differentiation that the rocks underwent.

The nomenclatures used for alkaline rocks involve modal, normative and genetic classifications, still considered by some to be controversial. The types of rocks commonly found in Alkaline Complexes [1] are carbonatites, phonolites, ijolites, phenites (alkaline magmatic alteration) and lamprophyres.

Some tectonic units of the South American Plate are associated with the occurrence of alkaline rocks [2]. Examples are Rio Grande Arch, Torres Syncline, 
Ponta Grossa Arch, Arch of Asuncion, Goiânia Fold, Arch of Alto Paranaíba, Arch of Bom Jardim de Goiás and São Silvestre Arch. Locally, alkaline rocks can also be found inYpacaraí (Eastern Paraguay), Paso do Marinheiro Transcurrent Fault System (Piratini Province) and Lancinha-Cubatão Transcurrent Fault System. Some authors [2] [3] recognize greater similarities between the alkaline rocks of the Southern Ribeira Belt and the Piratini(RS)Phonolitic Suite, rather than the Province of Santa Catarina, as would be expected by the geographical proximity.

Alkaline provinces are widespread in the South American Plate and have been grouped [2] into three distinct geographic situations:

1) Along the edges of the Paraná Basin;

2) In the Coastal Region, marginal to the Santos Basin; and

3) In the interior of the Amazonian Craton.

In this review, the authors have considered 12 provinces with rocks mainly of ultramafic trend (dunites and peridotites); alkaline trend (nephelinites, ijolites); carbonatite trend (ankerites, sovites) and lamprophyres trend (kimberlites and lamproites). It is also their understanding that the Alkali Complexes present in the Southern Ribeira Belt are related to the magmatism of Paraná-Etendeka Igneous Province, Ponta Grossa Arch and marginal areas to the Paraná Basin.

The most prominent complexes and alkaline plugs in the study region (Figure 1) are Tunas, Banhadão, Itapirapuã, Mato Preto, Barra do Itapirapuã, CatasAltas, SeteQuedas, Morro do Chapéu and Barra do Teixeira. Phonolites also occur in dykes, preferably in the NEE-SWW or E-W direction [4] in the Province of the Ponta Grossa Arch. Of the mentioned complexes, the one that presents some similarities with the rocks studied in this work is the Complex of Mato Preto. It contains rocks like ankerites and calcite carbonatites (absent in the study area), nepheline syenites, phonolites, phenites, tinguaites and less commonly ijolites, melteigites and volcanic breccias [5].

Dykes and alkaline plugs of the Ribeira Valley can be distinguished among Peralkaline Phonolites, Phonolites Stricto Sensu (s.s.), trachyphonolites, phonolithic nepheline phonolite and microsienites [3]. Fractional crystallization would be the main agent in the differentiation of these rocks. An age of $70 \mathrm{Ma}$ is considered appropriate for the most differentiated phonolite and $100 \mathrm{Ma}$ for phonolites rich in $\mathrm{Mg}$ (less differentiated) [3] [6] [7].

The petrogenetic models proposed to explain the origin of the alkaline rocks considered in this study are based mainly on the works of Le Bas (1977) [1] and Mitchell (1995) [4]. Some characteristics for the formation of these rocks are consensual. It is known that the geotectonic environment needed is intraplate, with direct participation of regional structures, such as rifts or lithospheric giant folds or local structures, like fault zones and diverse alignments. In addition, mantle magmatic sources are admitted, with little or no crustal contribution.

\section{Results and Discussion}

The petrographic analysis of the different rocks found in the study area (Figure 2) 




Figura 2. Schematic geologic map of the study area and mapped rocks. The numbers refer to exposures of alkaline rocks.

began in the field, with the description of 6 outcrops. The soil and vegetal cover in the region is intense, preventing the exposure of the rocks with greater frequency. Rocks belonging to the TrêsCórregos Granite Complex, which are mainly composed by sienogranites, monzogranites and porphyritic tonalities also occur in the area. They host the alkaline intrusions studied and have characteristics that are compatible with the alkaline rocks.

During field work, it was possible to identify some differences between the rocks sampled. The most distinctive feature being the changes brought about by weathering processes. This information, alongside macroscopic descriptions of the collected samples, allowed a preliminary separation into four main groups, namely phonolites (Figure 3(c), Figure 3(d)), amygdaloidal phonolites (Figure 4(a), Figure 4(b)), altered phonolites and fenites. Samples of the four groups were selected for analyses. Subsequently, with the descriptions of thin sections and data on treatment of chemical analyzes, the following nomenclatures were adopted for the classification of the studied rocks: phonolite, amygdaloidal phonolite, trachyphonolite and epidote fenites.

\subsection{Phonolites}

The phonolites s.s. (Figure 3(c), Figure 3(d)) are well exposed in points 56, 57 and 118 (Figure 2). They present macroscopic features such as: gray or greenish gray color when unaltered and beige when altered; Porphyritic inequigranular texture, with about $5 \%$ phenocrysts (mainly of nepheline and potassic feldspar) and $95 \%$ of very fine matrix (aphanitic). The structure of these rocks is mainly massive and rarely of incipient magmatic flow, defined by oriented phenocrystals. 


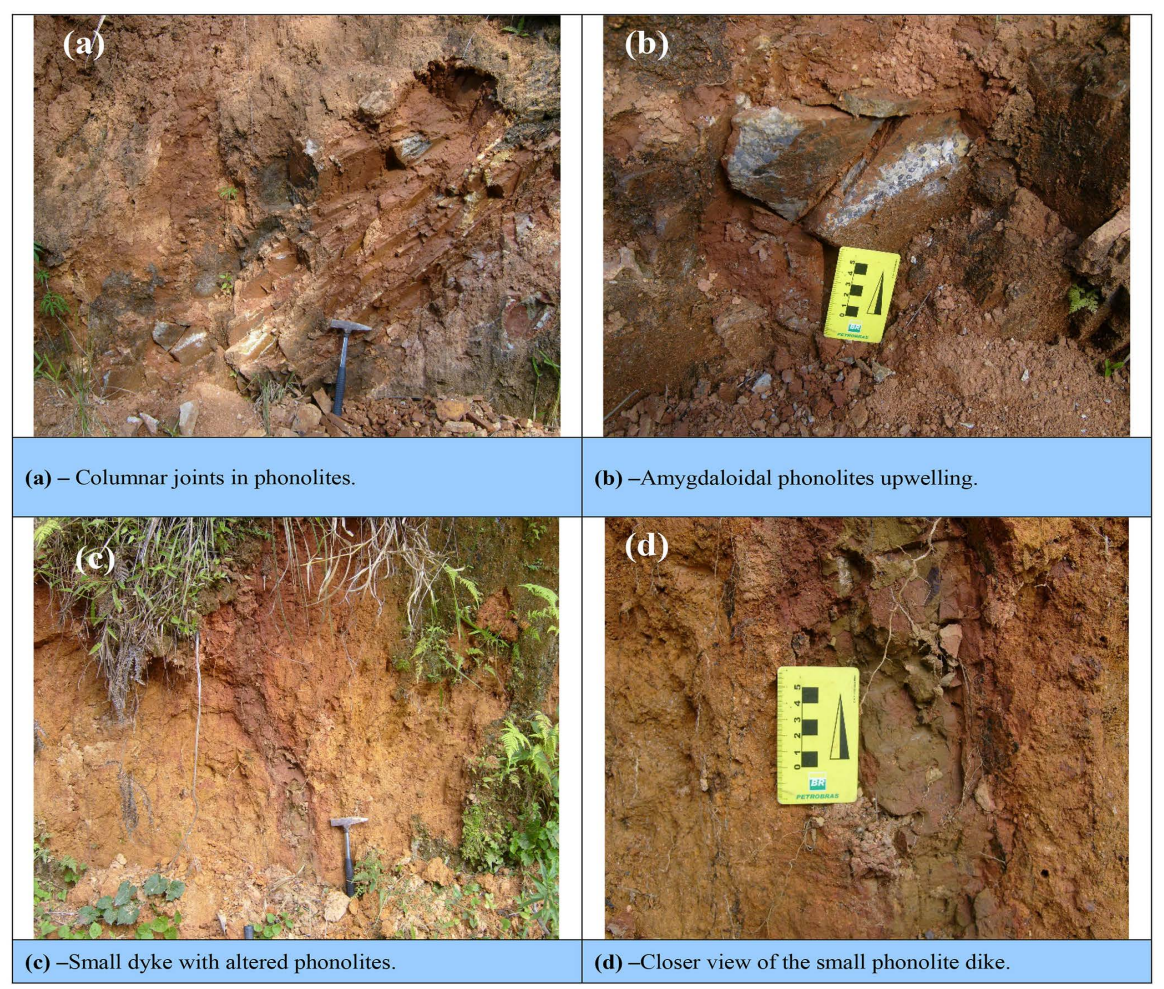

Figure 3. Anta gorda alkaline dyke.

For this lithology, three petrographic thin sections were made. The microscopic characteristics in common are porphyritic inequigranular texture and flow structures defined by the orientation of the phenocrysts. Another observed feature is the unusual presence of thin nepheline veins discordant with rock structures.

The main mineral component of the phonolites s.s. is nepheline. It accounts for $30 \%$ to $60 \%$ of the rocks, $50 \%$ being a representative value. Nepheline is found as phenocrysts (Figure 4(a), Figure 4(b)) that can reach up to $2 \mathrm{~cm}$ along the major axis, but is also found as microphenocrysts (Figure 4(c), Figure 4(d)) in the matrix.

Sanidine is identified as the primary alkali feldspar in this lithology. Like nepheline, it may occur as phenocrysts, but it is predominantly the mineral constituent of the matrix. It can represent between 15 and $45 \%$ in the range and an average of $30 \%$ is a valid mean for Sanidine.

Clinopyroxenes were also described as modal minerals of phonolites s.s. Identified in the slides as aegirine-augite (Figure 4(e), Figure 4(f)), this mineral is exclusively in the matrix and corresponds for $20 \%$ to $25 \%$ of the rocks. Sometimes, they are associated with features, such as aggregates of pyroxenes, sometimes included in crystals of nepheline or sanidine, and sometimes in hexagonal aggregates, which are common in all samples. These features define a texture of rapid cooling and growth for the minerals (spherulitic texture).

Trace minerals, such as biotite, diopside and opaques are commonly observed, and may occasionally contain reaction edges with aegirine-augite (Figure 6(f)). 


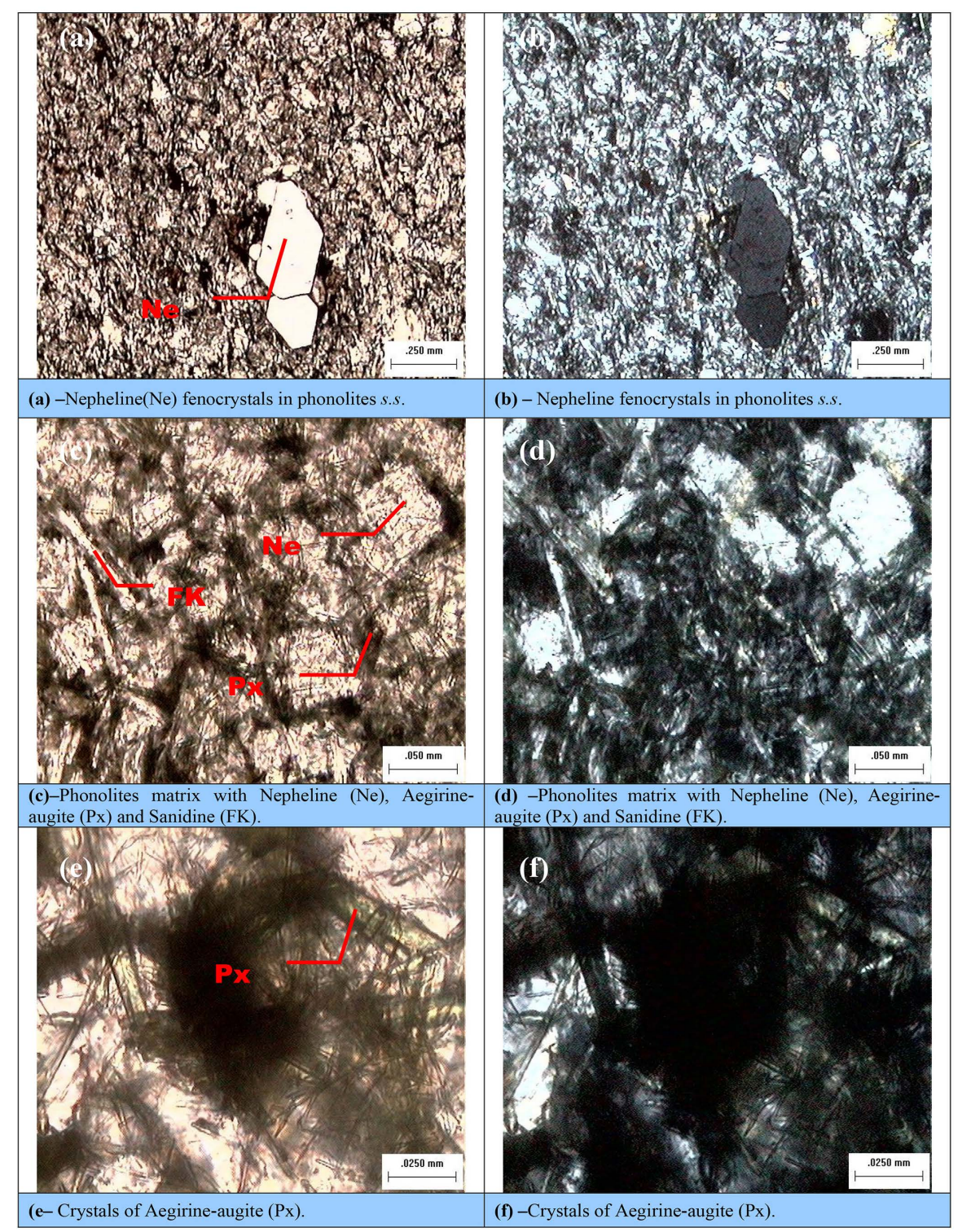

Figure 4. Photomicrographs of phonolites s.s. of Anta Gorda Alkaline Dyke.

The most common accessories in phonolites s.s. are titanite, zircon, epidote and apatite; the last three as inclusions, mainly in nepheline and sanidine phenocrysts.

\subsection{Amygdaloidal Phonolites}

Phonolites with amygdaloidal structures are found mainly in points 56 and 57, occur intercalated with phonolites s.s. (Figure 3(a), Figure 3(b)), and are controlled by a penetrative system of fractures N55E/70SE, probably columnar jointed. This lithology presents specific macroscopic characteristics, generally observed as three levels of different textures and colors, with centimetric banding. The individualization of this lithotype, in addition to the structures mentioned, point to at least two alteration phases in these rocks, which will be discussed below. 
In macroscopic samples, this lithotype mainly presents three levels of colors and different textures. In the first level are observed colors in between beige and light brown, very fine granulation (aphanitic), containing figures of oxidation. The second level has purple color, fine granulation and internal banding with levels that have a stronger or weaker shade of purple. The third level is also characterized by a purple color, very fine granulation and higher concentration of purple spheres or amygdala (Figure 5(c), Figure 5(d)).

Nepheline is also the main constituent in the amygdaloidal phonolites. They are exclusively matrix crystals, showing anhedral habits, probably because the substitution of this mineral by the zeolite in these rocks is larger. It represents between $40 \%$ and $60 \%$ of the composition and is homogeneously distributed at all rock levels.

Sanidine is found making up between $20 \%$ and $30 \%$ of the matrix (a single phenocrystal observed) with a subhedral euhedral.

In the amygdaloidal phonolites, clinopyroxenes are not observed, being completely replaced by opaque oxides or hydroxide (goethite), which together can represent 20 to $30 \%$ of the samples.

Fluorite traces are interpreted as present in the rock. This mineral would be responsible for the purple levels (Figure 5(a), Figure 5(b)). On thin section, levels containing a greater concentration of holes with square or rectangular forms are observed. It is possible that these holes were created with the removal of low hardness fluorite during preparation.

Biotite, calcite and celadonite are also traces in the amygdaloidal phonoliths. Biotite was observed as a single crystal in one sample, with acicular euhedral habit. Calcite and celadonite are unique minerals in filling the amygdala, accompanied by zeolites. Epidote is the only accessory mineral observed.

\subsection{Trachyphonolites}

This group of rocks is very similar to the phonolites s.s. and was individualized for textural reasons, besides having different geochemical characteristics. The outcrops are located mainly in the northeastern portion of the alkali dyke, and have an exposure at point 125 (Figure 3(c), Figure 3(d)). These rocks were initially called altered phonolites and, macroscopically, show very light gray color, porphyritic inequigranular texture, fine granulation of the matrix (aphanitic) and massive structure, often showing cavities where there once were feldspar or feldspathoid crystals.

Microscopically (Figure 6(c), Figure 6(d), Figure 6(e)), a trachytic porphyritic inequigranular texture is observed, defined by the strong orientation of sanidine crystals in the rock matrix. One sample in which nepheline is practically absent was analyzed; only the habit of the crystal remained, the mineral having been entirely replaced by zeolites (Figure 6(a), Figure 6(b)).

The zeolite is the main mineral present in this rock, comprising about $50 \%$ in the samples. Sanidine is an important mineral as well, making up about $35 \%$ of the matrix of the trachyphonolites, Finally, oxides and hydroxides were described 


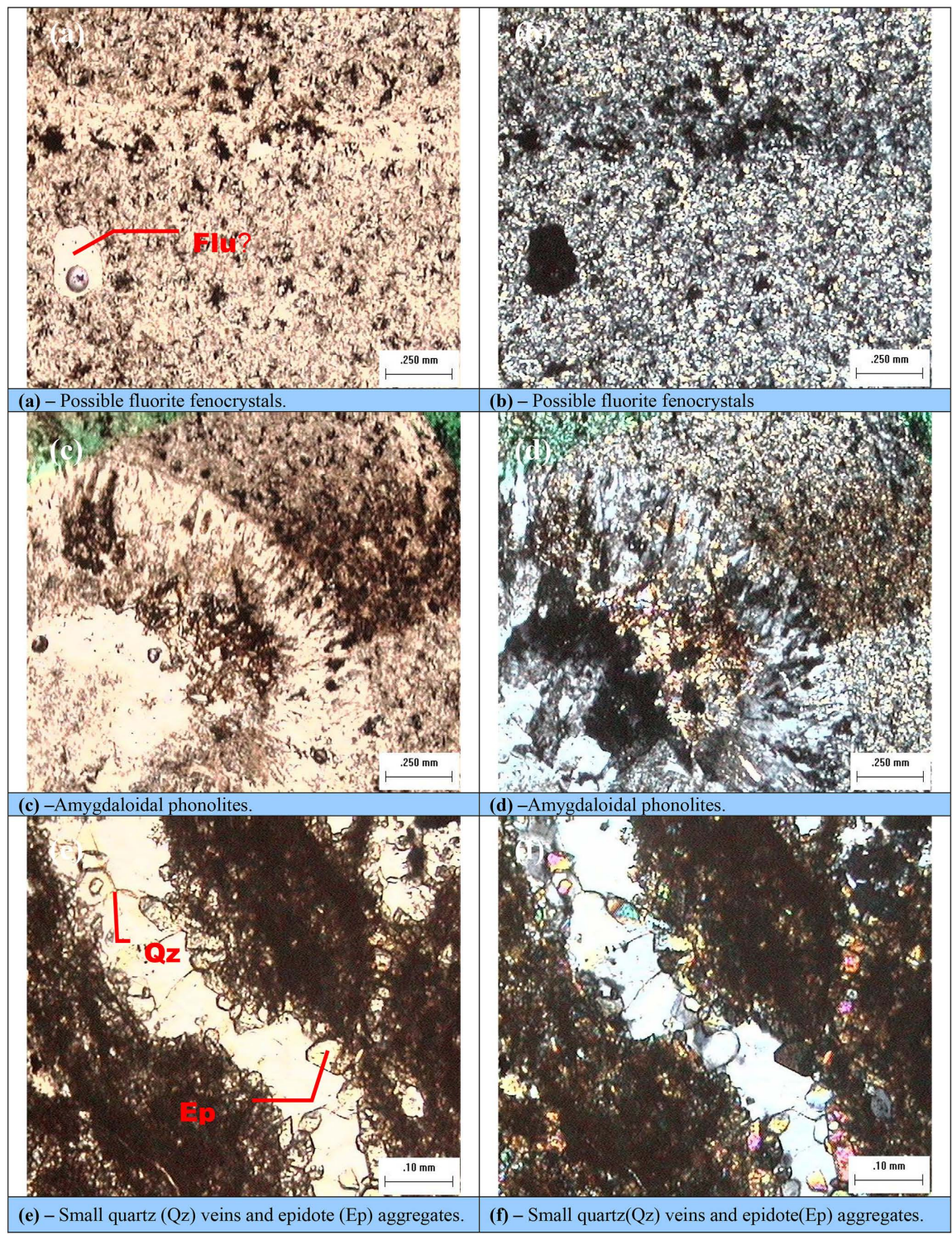

Figure 5. Photomicrographs of amygdaloidal phonolites (a), (b), (c), (d) and epidote fenites ((e), (f)) of Anta Gorda Dyke.

as composing about $15 \%$ of the rock, probably coming from the supergenic alteration of aegirine-augite and opaque trace.

\subsection{Epidote Fenites}

Although the association of this group of rocks with the phonolites studied is suggested, it should not be admitted as conclusive. Firstly, no in situ outcrop of this lithology was found, making it impossible to verify the contact relations between these alkaline rocks. Secondly, this type of alteration is considered unusual for the geological situation of the Anta Gorda alkali dyke. Blocks of this lithotype were found at point 123 ( $\mathrm{a}$ and $\mathrm{b}$ ) of the study area as macroscopically pale yellowish or greenish rocks, with breccia appearance, a very fine textured matrix (aphanitic) and thin quartz veins, showing some red "breccia fragments". 


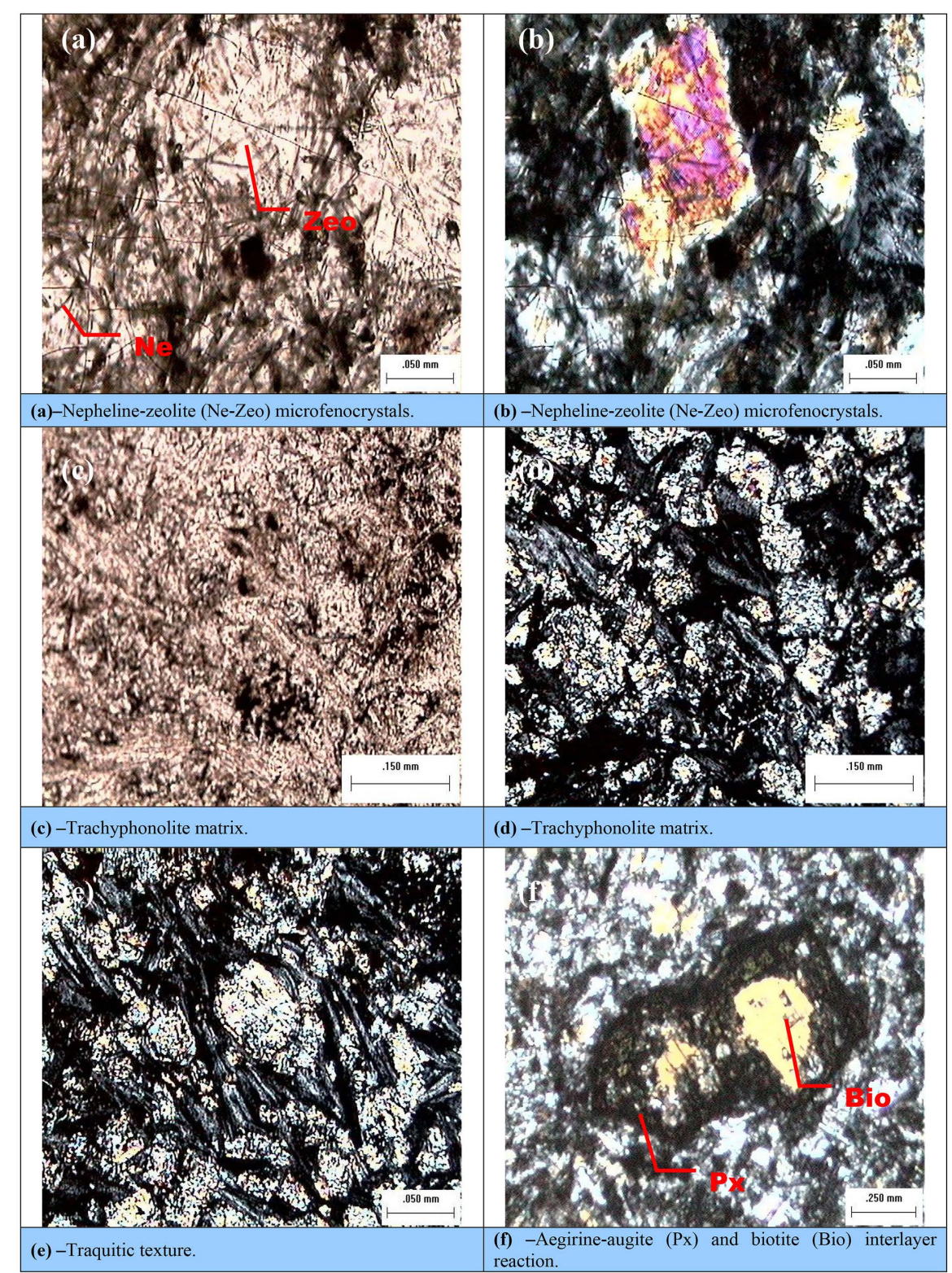

Figure 6. Photomicrographs of phonolites s.s. (a), (b), (f) and trachyphonolites (c), (d), (e) of Anta Gorda Alkaline Dyke.

In the epidote fenites (Figure 5(e), Figure 5(f)) several small/micro quartz veins or venules were observed, with less frequent opaque minerals; Very fine inequigranular texture was seen in the substitution mineral mass, and fine in the quartz crystals in the veins. The rock is deformed with high undulating extinction and fracturing in the quartz.

Quartz is the main mineral in the composition of this rock and it appears both as very fractured crystals with strong undulating extinction-probably remnant of the nesting rock of the TrêsCórregos Granite Complex-and, in smaller proportion, as microfractures filling, developing small/micro veins or venules. All quartz corresponds to approximately $45 \%$ of the rock.

A substitution mass formed by epidotes (35\%), chlorite (10\%) and opaque 
minerals (10\%) completes the composition of the rocks. The epidote has light brown color, euhedral (prismatic) and anhedral habit, and occurs in aggregates (ghost texture) or crystals, better developed in the quartz veins. Traces of biotite are also observed in the samples. The fragments of breccia are, in fact, the form in which this substitution mass occurs; in the same habit of the mafic minerals and feldspars that have been replaced, giving the rocks a ghost texture.

\subsection{Geochemistry}

The diffraction analyzes (Table 1) were made for three lithological groups: phonolites s.s., amygdaloidal phonolites and trachyphonolites. This technique was used to aid petrography and the interpretation of the mineral phases present in the rocks. It was exclusively qualitative and essential in distinguishing minerals with difficult characterization in petrographic analyses.

The characterization of the zeolites from the nepheline alteration was possible in these analyzes. It was revealed that a first phase of hydration was responsible for the formation of natrolite in phonolites s.s. As this process continued, mesolite, which is present in all samples, was crystallized. The technique didn't reveal the presence or absence of fluorite crystals in the amygdaloidal phonoliths. Nevertheless, this mineral was included in the interpretation, as all peaks in the diffractogram suggested its presence. Finally, a white muscovite was characterized for the alteration of the sanidine and minerals previously treated as oxides and hydroxides, mainly hematite and goethite, respectively.

The same rocks were also subjected to X-ray Fluorescence analyzes (Table 2). Sample 57 A corresponds to a phonolite s.sand was analyzed quantitatively, with reading only of the larger elements, which implied greater precision of results. The amygdaloidal phonolite (57C) and trachyphonolite (125) were analyzed semi-quantitatively, with reading of larger elements and some trace elements, implying less accurate results. Discrepant responses were observed mainly in silica, sodium, carbonate and iron oxide. The trace element contents are only cited for comparison purposes, as the accuracy of the reading is very low, making the use of the data unfeasible.

The classifications adopted for the studied rocks also originated from the results of chemical data projections, mainly TAS diagrams $\left\{\left(\mathrm{Na}_{2} \mathrm{O}+\mathrm{K}_{2} \mathrm{O}\right)-\mathrm{SiO}_{2}\right\}$. The data was plotted in the diagram R1R2 $\{\mathrm{R} 1=4 \mathrm{Si}-11(\mathrm{Na}+\mathrm{K})-2(\mathrm{Fe}+\mathrm{Ti})$ and $\mathrm{R} 2=6 \mathrm{Ca}-2 \mathrm{Mg}+\mathrm{Al}\}$, proposed by De La Roche et al. (1980) [8]. The responses were: sample $57 \mathrm{~A}$ (phonolith s.s.) in the field of phonolith, and samples 57C (amyloid phonolith) and 125 (trachyphonolith) in the field of trachyphonolith. Because the diagram is drawn with many of the elements considered for imprecise samples $57 \mathrm{C}$ and 125 , it will not be illustrated. However, the phonolite s.s classification for sample $57 \mathrm{~A}$ is valid.

The TAS diagrams used in the geochemical classification are from Le Bas (1989 [9]; Figure 7) and Le Maitre (1989) [10]. However, in this case, the maximum value of alkalis considered by the author is $16 \%$. That is why sample $57 \mathrm{~A}$ of phonolite s.s, with the sum $\mathrm{Na}_{2} \mathrm{O}+\mathrm{K}_{2} \mathrm{O}$ equal to $17.3 \%$ is not projected in the 
Table 1. Interpretation of diffractometry analyses (qualitative). Samples: 57A-Phonolite s.s.; 57C-Amygdaloidal phonolite and 125-Trachyphonolite. Score is the probability of occurrence (gray cell with 0 value means absent mineral).

\begin{tabular}{|c|c|c|c|c|}
\hline Mineral & $\begin{array}{c}\text { Score } \\
57 \mathrm{~A}\end{array}$ & $\begin{array}{c}\text { Score } \\
57 \mathrm{C}\end{array}$ & $\begin{array}{c}\text { Score } \\
125\end{array}$ & Chemical formula \\
\hline Nepheline & 70 & 34 & 35 & $\mathrm{Na}_{2} \cdot 8 \mathrm{~K} \cdot 6 \mathrm{Ca} \cdot 2 \mathrm{Al}_{3} \cdot 8 \mathrm{Si}_{4} \cdot 2 \mathrm{O}_{16}$ \\
\hline Sanidine & 58 & 63 & 61 & $\mathrm{~K} \mathrm{Al} \mathrm{Si}_{3} \mathrm{O}_{8}$ \\
\hline Mesolite & 39 & 25 & 31 & $\mathrm{Na}_{2} \mathrm{Ca}_{2} \mathrm{Al}_{6} \mathrm{Si}_{9} \mathrm{O}_{30} 8 \mathrm{H}_{2} \mathrm{O}$ \\
\hline Natrolite & 46 & 0 & 0 & $\mathrm{Na}_{15.5} \mathrm{~K}_{0.5} \mathrm{Al}_{16} \mathrm{Si}_{24} \mathrm{O}_{80} 16 \mathrm{H}_{2} \mathrm{O}$ \\
\hline Aegirine-augite & 33 & 0 & 23 & $(\mathrm{Na}, \mathrm{Ca}) \mathrm{Fe}^{3+} \mathrm{Si}_{2} \mathrm{O}_{6}$ \\
\hline Titanite & 36 & 0 & 0 & $\mathrm{CaTiOSiO}_{4}$ \\
\hline Zircon & 39 & 0 & 0 & $\mathrm{ZrSiO}_{4}$ \\
\hline Augite & 40 & 0 & 0 & Na.1 Ca.6 Mg. 9 Fe. 2 Ti.0 Al. 3 Si1. $8 \mathrm{O}_{6}$ \\
\hline Muscovite & 0 & 0 & 41 & $\mathrm{~K} \mathrm{Al} 2\left(\mathrm{Si}_{3} \mathrm{Al}\right) \mathrm{O}_{10}(\mathrm{OH})_{2}$ \\
\hline Biotite & 0 & 33 & 0 & $2\left(\mathrm{Mg}, \mathrm{Fe}^{2+}\right) \mathrm{O}(\mathrm{K}, \mathrm{H})_{2} \mathrm{O}\left(\mathrm{Al}, \mathrm{Fe}^{3+}\right) 2 \mathrm{O}_{3} \mathrm{SiO}_{2}$ \\
\hline Hematite & 0 & 26 & 44 & $\mathrm{Fe}_{2} \mathrm{O}_{3}$ \\
\hline Goethite & 0 & 21 & 0 & $\mathrm{Fe}_{2} \mathrm{O}_{3} \cdot \mathrm{H}_{2} \mathrm{O}$ \\
\hline Fluorite? & 0 & 23 & 0 & $\mathrm{Ca} \mathrm{F}_{2}$ \\
\hline Celadonite & 0 & 30 & 0 & $\mathrm{~K}\left(\mathrm{Mg}, \mathrm{Fe}^{2+}\right)\left(\mathrm{Fe}^{3+}, \mathrm{Al}\right) \mathrm{Si}_{4} \mathrm{O}_{10}(\mathrm{OH})_{2}$ \\
\hline
\end{tabular}

Table 2. X-Ray Fluorescence analyses. Samples: 57A—Phonolite s.s.; 57C-Amygdaloidal phonolite and 125-Traquiphonolite. L.O.I = loss on ignition; I.A = agpaitic index.

\begin{tabular}{ccccccc}
\hline & Oxides (\%) & & \multicolumn{5}{c}{ Trace elements (ppm) } \\
\hline Sample & $\mathbf{5 7 A}$ & $\mathbf{5 7 C}$ & $\mathbf{1 2 5}$ & Sample & $\mathbf{5 7 C}$ & $\mathbf{1 2 5}$ \\
\hline $\mathrm{SiO}_{2}$ & 53.67 & 61.46 & 63.47 & $\mathrm{Y}_{2} \mathrm{O}_{3}$ & 190 & 190 \\
$\mathrm{Al}_{2} \mathrm{O}_{3}$ & 21.57 & 23.58 & 22.17 & $\mathrm{ZrO}_{2}$ & 90 & 70 \\
$\mathrm{Fe}_{2} \mathrm{O}_{3}$ & 4.46 & 2.55 & 1.96 & $\mathrm{BaO}$ & 60 & 70 \\
$\mathrm{CaO}$ & 1.40 & 0.02 & 0.02 & $\mathrm{SrO}$ & 40 & 50 \\
$\mathrm{~K}_{2} \mathrm{O}$ & 9.01 & 11.00 & 11.16 & $\mathrm{Rb}_{2} \mathrm{O}$ & 30 & 30 \\
$\mathrm{Na}_{2} \mathrm{O}$ & 8.29 & 0.20 & 0.38 & $\mathrm{SO}_{3}$ & 20 & 10 \\
$\mathrm{MgO}$ & 0.19 & 0.11 & 0.07 & $\mathrm{ZnO}$ & 10 & 10 \\
$\mathrm{MnO}$ & 0.12 & 0.06 & 0.07 & $\mathrm{ThO}_{2}$ & 0 & \\
$\mathrm{TiO}_{2}$ & 0.53 & 0.49 & 0.33 & $\mathrm{Ga}_{2} \mathrm{O}_{3}$ & 0 & \\
$\mathrm{P}_{2} \mathrm{O}_{5}$ & 0.08 & 0.09 & 0.09 & & & \\
$\mathrm{Total}$ & 99.32 & 99.56 & 99.72 & $\mathrm{Total}$ & 440 & \\
L.O.I & 1.91 & 2.31 & 2.52 & & & \\
$\mathrm{I} . \mathrm{A}$ & 0.80 & 0.48 & 0.52 & &
\end{tabular}

diagram. For the Le Maitre TAS diagram (Figure 8). Alkali values of up to $20 \%$ are considered in the rocks. According to schemes of bothauthors, the rock $57 \mathrm{~A}$ should be classified as a phonolite and $57 \mathrm{C}$ and 125 as trachytes. 


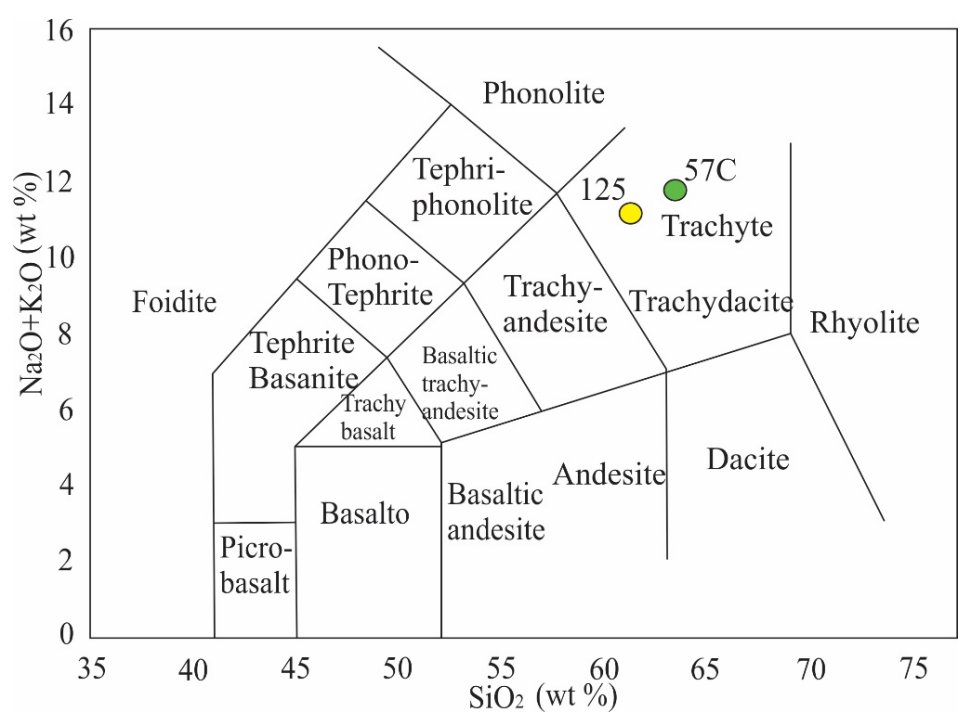

Figure 7. TAS diagram of Le Maitre (1989) [9]. Samples: 57C-Amygdaloidal phonolite and 12-Trachyphonolite.

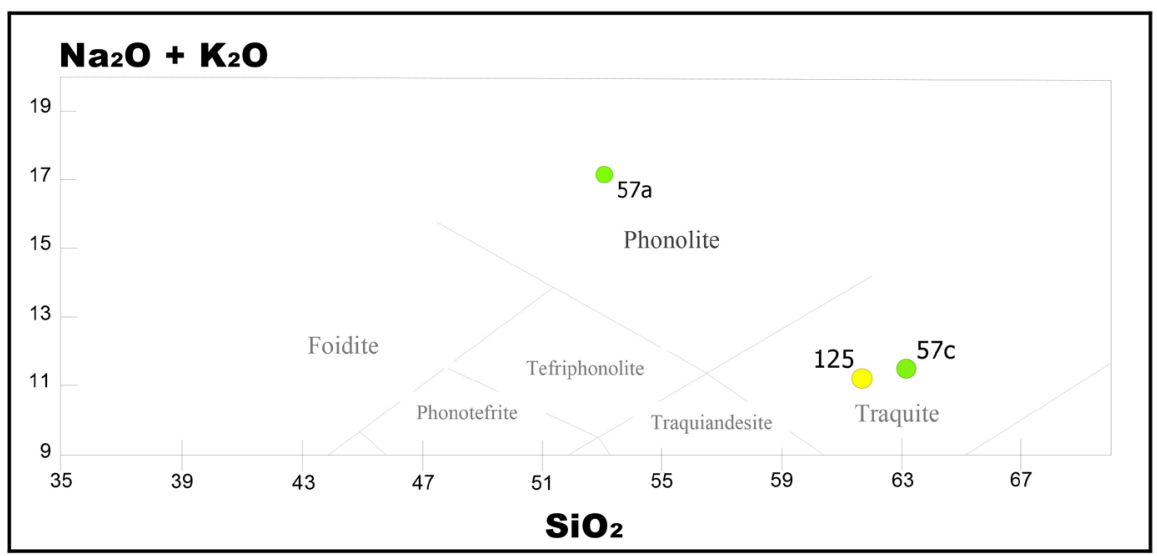

Figure 8. TAS diagram of Le Maitre (1989) [9]. Samples: 57A-Phonolite s.s.; 57CAmygdaloidal phonolite and 125-Traquiphonolite.

The agpaitic index $\left\{\mathrm{I} . \mathrm{A}=\left(\mathrm{Na}_{2} \mathrm{O}+\mathrm{K}_{2} \mathrm{O}\right) / \mathrm{Al}_{2} \mathrm{O}_{3}\right\}$ is best represented by the mean value of 0.80 , calculated from the quantitative analysis. When this value is greater than 1, the phonolites should be treated as peralkaline phonolites. The studied lithotypes of the Anta Gorda alkali dyke were individualized into four groups, the classification adopted is based on at least two striking characteristics for each group. Textural, structural, mineralogical or geochemical composition and possible associations with hydrothermal fluids were considered important.

\subsection{Petrogenesis}

Some considerations regarding the geological evolution of the Anta Gorda alkali dyke will be mentioned in this chapter, but it should be emphasized that this is not the main objective of the present research. The development of the magmatic and metasomatic events is interpreted as the main forming agents of the stu- 
died rocks, and the proposition of the evolutionary model for the alkali dyke is admitted as "embryonic", lacking in information and refinement.

\subsection{Magmatism}

The main processes involved in the formation of alkaline rocks are magmatic, directly responsible for the crystallization of phonolites s.s., amygdaloidal phonolites and trachyphonolites. The magmatic activity generating these lithologies is preceded by the tectonism that allowed the lodging of this intrusion at crustal level, in which it is found. Probably, the rise mechanism in this case is decompressive, with mantle fusion from the pressure relief.

The first magmatic event is attributed to the generation of ultrabasic magma, with a carbonated lherzolite source [1] [11] in deep mantle (100 - $200 \mathrm{~km})$. From this magma, the first differentiation event occurs; after the fractioning of mafic and alkalis, a nefelinitic immiscible liquid is created. In this situation, the fractional crystallization in a closed system, that is, without crustal contribution, is responsible for the rest of the magmatic differentiation in these rocks. Also $\mathrm{Ru}-$ berti et al. 2012 concluded that the parental magmas of both series of Banhadão Alkaline Complex (Ca- and Ti-rich series and $\mathrm{Ca}$ - and Ti-poor series) were generated from a $\mathrm{CO}_{2}$-rich potassic metasomatized lithospheric mantle enriched with rutile-bearing phlogopite clinopyroxenite veins and that the low-Ca series was likely crystallized from a phonolite magma that represents the evolved fraction of primary potassic nephelinite magma [12].

The Vasconcellos (1995) model is accepted in this work, with differentiation from phonolithic nephelinites (Figure 9) for the phonolites studied. Petrographic and geochemical evidences suggest that for the rocks of the Anta Gorda alkali dyke, trachyphonolites are less evolved than phonolites s.s.

\subsection{Fenitization}

The process proposed for the generation of the epidotes fenites studied involves the participation of fluid with alkaline magmatic origin. The alteration paragenesis found does not correspond to products that would be expected from the action of potassium or sodium fluids in this geological situation. Therefore, the calcium origin must be attributed to the nesting rock or to a possible carbonated magmatic pulse.

The description of this type of rock is considered of great importance, as it is a clue for the characterization of the fluid phase that accompanies the magmatic activity. Other guides would be the analysis of fluid inclusions and description of late minerals that fill holes or microfractures in the rocks. Amygdaloidal phonolites are rocks that may indicate some of these fluid characteristics, since they have hydrothermal minerals, such as calcite, celadonite and possibly fluorite.

\subsection{Economic Possibilities}

The similarities between the Anta Gorda alkali dyke and the Mato Preto Alkaline Complex go beyond a possible fluoride-enriched fluid. Jenkins II (1987) [5] 


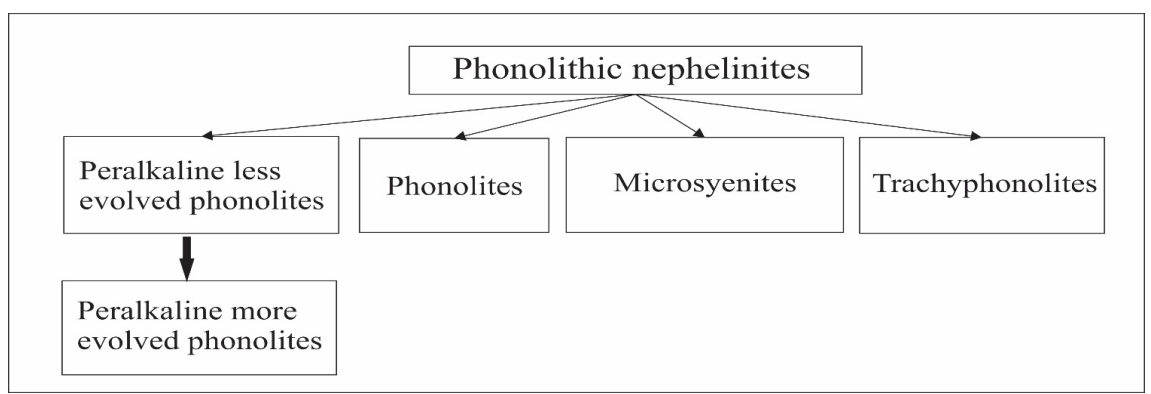

Figure 9. Differentiation from fractional crystallization, to alkaline dykes and plugs of the Ribeira Valley (Source: Vasconcellos, 1995 [3]).

described some important characteristics of the fluorite ore body, which is directly associated with phonolite intrusions, with $40 \%$ - 70\% nepheline, 30\% $40 \%$ aegirine-augite, $25 \%$ alkali feldspar, and fluorite "enveloping" the phonolites. In a first hydrothermal alteration phase, the phonolites would have produced an aureole of epidote alteration (Figure 10).

The phonolites studied are so similar to the ones from Mato Preto, that [3] the study of much of the alkaline rocks of the region showed that the only phonoliths s.s. (I.A less than 1) and trachyphonoliths are upwelling in the Mato Preto Complex. The phonolites s.s. of Anta Gorda have I.A of 0.80 and are also described in this dyke trachyphonolite dyke.

During field studies, no levels were found with representative concentrations of fluorite, nor is the presence of this mineral in the samples collected. Between the purple color of the amygdaloidal phonolites and the X-ray diffraction analysis, there is still little information regarding this matter.

Considering the similarities between Anta Gorda and Mato Preto phonolites, the most promising economic potential lies in mineralizations of rare earth elements, which were not passable of chemical analysis. The concentrations of Er, $\mathrm{Tm}, \mathrm{Yb}$ and $\mathrm{Lu}$ in the trachyphonolites are up to $945 \mathrm{ppm}$ in Mato Preto. Vasconcellos (1995) [3] also cites significant concentrations of trace elements in the peralkaline phonolites and trachyphonolites. Apparently, the highest concentration found in the rocks of Anta Gorda is $190 \mathrm{ppm}$ of $\mathrm{Y}_{2} \mathrm{O}_{3}$.

Weathering processes are identified on phonolites of the Anta Gorda alkali dyke, and may be responsible for supergenic concentrations, mainly of alumina and potassium. This type of enriched material, with low iron oxide content is widely used in the white and refractory ceramic industries. It is mainly found at point 125 and may contain up to $11.16 \% \mathrm{~K}_{2} \mathrm{O} ; 22.17 \% \mathrm{Al}_{2} \mathrm{O}_{3}$ and $1.93 \% \mathrm{Fe}_{2} \mathrm{O}_{3}$, corresponding to altered trachyphonolites.

Finally, the concentration of zeolites is considered of economic interest as well. Both natrolite and mesolite have applications as filters for oils, among other things. These minerals are also products of chemical weathering, mainly of nepheline hydration. A zeolite count was performed on a petrographical analyse for a phonolite s.s, and for every five nepheline crystals, there is one of zeolite $(\mathrm{Zeo} / \mathrm{Ne}=1 / 5$ ratio). In altered trachyphonolites this ratio is reversed. 


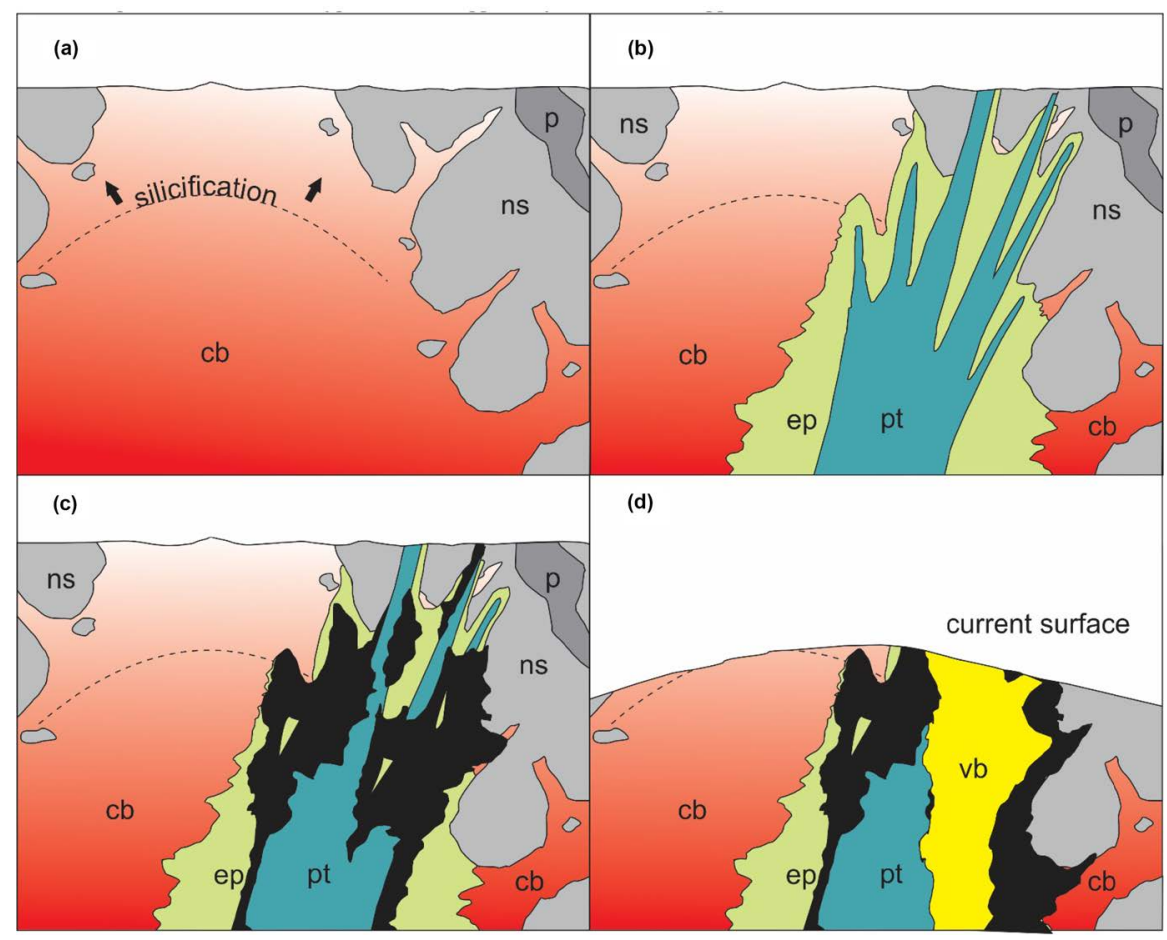

Figure 10. Schematic section showing fluorite ore evolution in Mato Preto. Legend: ns-nepheline syenite; $\mathrm{cb}$-carbonatite; $\mathrm{p}$-phonolite;pt-phonolite-tinguaite; ep-epidote alteration and low grade mineralization; vb-volcanic breccia, solid black denotes high-grade mineralization (Source: Jenkins II, 1987 [5]).

All hypotheses presented for mineralizations in the studied region should be considered conclusions of a first stage of research. The characteristics observed and described do not make the Anta Gorda alkaline dyke a mineral occurrence, only a research target.

\section{Conclusions and Recommendations}

This research presented four groups of rocks. Three of them (phonolites s.s., amygdaloidal phonolites and trachyphonolites) are considered to be a direct derivation of nephelinite prime magmas with ultrabasic mantle sources (carbonated lherzolites). The possible main processes of differentiation are immiscibility of the nephelinite liquid, and fractional crystallization. A fourth lithological group, epidote phenites, is also interpreted in this study, as representative of the process of fenitization in granitic nesting rock.

The research was possible because of petrography and geochemistry data. When compared to bibliographical data, the results point to greater similarities between phonolites of the Anta Gorda alkali dyke and those of the Mato Preto Alkaline Complex, rather than the alkaline plug Barra do Teixeira or Banhadão Alkaline Complex, in spite of the geographical proximity with the latter.

The characterization of a mineral occurrence with the media used was not possible. But the economic possibilities for the studied rocks are seen as promising, especially for rare earth elements, trace elements and zeolites. Despite the 
fact that the dykes are not so large, the abundance of these structures raises new exploratory possibilities in the southern Ribeira Belt.

\section{Conflicts of Interest}

The authors declare no conflicts of interest regarding the publication of this paper.

\section{References}

[1] Le Bas, M.J. (1977) Carbonatite-Nephelinite Volcanism. John Wiley \& Sons, Hoboken, NJ, 327 p.

[2] Almeida, F.F.M. (1983) Relações tectônicas das rochas alcalinas mesozóicas da região meridional da plataforma Sul-Americana. Revista Brasileira de Geociências, 13, 139-158. https://doi.org/10.25249/0375-7536.1983133139158

[3] Vasconcellos, E.M.G. (1995) Petrologia e geoquímica de diques e "plugs" alcalinos da região do Vale do Ribeira, divisa dos estados do Paraná e São Paulo. Tese de Doutoramento. Instituto de Geociências, Universidade de São Paulo, São Paulo, 202 p.

[4] Loureiro Lapido, F.E. and Tavares, J.R. (1983) Duas novas ocorrências de carbonatitos: Mato Preto e Barra do Rio Itapirapuã. Revista Brasileira de Geociências, 13, 7-11. https://doi.org/10.25249/0375-7536.19831310711

[5] Jenkins, R.E. (1987) Geology of the Clugger Fluorite Deposit, Mato Preto Paraná, Brazil. Revista Brasileira de Geociências, 17, 288-294.

https://doi.org/10.25249/0375-7536.1987288294

[6] Comin-Chiaramonti, P., Gomes, C.B., Ruberti, E., Antonini, P., Castorina, F. and Censi, P. (2001) Mato Preto Alkaline-Carbonatite Complex: Geochemistry and Isotope (O-C and Sr-Nd) Constraints. Geochimica Brasiliensis, 15, 23-34.

[7] Gomes, C.B., Azzone, R.G., Ruberti, E., Vasconcelos, P.M., Sato, K. and Rojas, G.E.E. (2018) New Age Determinations for the Banhadão and Itapirapuã Complexes in the Ribeira Valley, Southern Brazil. Brazilian Journal of Geology, 48, 403-414. https://doi.org/10.1590/2317-4889201820170094

[8] De la Roche, H., Leterrier, J., Grandclaude, P. and Marchal, M. (1980) A Classification of Volcanic and Plutonic Rocks Using $R_{1} R_{2}$-Diagram and Major Element Analyses-Its Relationships with Current Nomenclature. Chemical Geology, 29, 183-201. https://doi.org/10.1016/0009-2541(80)90020-0

[9] Le Bas, M.J. (1989) Nephelinitic and Basanitic Rocks. Journal of Petrology, 30, 1299-1312. https://doi.org/10.1093/petrology/30.5.1299

[10] Le Maitre, R.W. (1989) A Classification of Igneous Rocks and Glossary Terms. 2nd Edition, Blackwell Scientific Publications, Oxford, 193 p.

[11] Mitchell, R.H. (1995) Kimberlites, Orangeites and Related Rocks. Plenum Press, New York, 410 p. https://doi.org/10.1007/978-1-4615-1993-5

[12] Ruberti, E., Azzone, R.G., Rojas, G.E.E. and Comin-Chiaramonti, P. (2012) The Banhadão Alkaline Complex, Southeastern Brazil: Source and Evolution of Potassic $\mathrm{SiO}_{2}$-Undersaturated High-Ca and Low-Ca Magmatic Series. Mineralogy and Petrology, 104, 63-80. https://doi.org/10.1007/s00710-011-0171-9 